\title{
Optimization and Standardisation of Waste Cooking Oil into Bio- Diesel
}

\author{
Mr.Ankit Kumar, Rahul Rana,NavdeepNandal,Mohit Singh, Narender Singh \\ Department of Mechanical Engineering,Affilated to KurukshetraUniversity, Kurukshetra \\ Guru Nanak Institutions, Mullana, Ambala,India
}

\begin{abstract}
The study was conducted to investigate the optimum conditions for biodiesel formation from waste cooking oil coming after alkaline transesterification process in combination with methanol. Some important variables such as volumetric ratio, types of reactants and catalytic activities were selected to obtain a high quality biodiesel fuel with the specification of American Society Of Testing and Materials. The research investigates the biodiesel obtained under optimum conditions from waste cooking oil of good quality and could be used as a diesel fuel which considered as potential use of waste cooking oil.
\end{abstract}

Keywords: Biodeisel, methanol, waste oil, transesterification.

Abbreviations: Waste cooking oil, American Society Of Testing and Materials.

\section{Introduction}

New alternative and renewable fuel(biodiesel) has received a considerable attention recently due to occurance of oil depletion, global warming and green house effect. Biodiesel is a good alternative energy which is one of the most promising energy sources. In accordance with the US standards specifications of biodiesel, it is non toxic, biodegradable, produced from renewable sources and contributes a minimal amount of net green house gases and contributes such as $\mathrm{CO} 2$ and $\mathrm{NO} 2$ emission and sulphur to the atmosphere.The high viscocity and poor volatility are major limitations of vegetable oil for their utilisation as fuel in diesel engines. Among more then 350 identified oil bearing crops only sunflower, soyabean are considered as potential alternative fuel for diesel engines. The large amount of waste cooking oil was produced from restaurents, catering establishment and food industries every year. The objective of this study were to compare optimum conditions of fatty acids methyl easter and potential use of waste cooking oil.

\section{Materials and Methods}

Materials: Waste cooking oil, Potassium Hydroxide, Methanol.

Method: Transesterification reaction

$$
\begin{aligned}
& \mathrm{H} 2 \mathrm{C}-\mathrm{OOC}-\mathrm{R} 1 \quad \mathrm{CH} 3-\mathrm{OOC}-\mathrm{R} 1 \mathrm{H} 2 \mathrm{C}-\mathrm{OH} \\
& \mathrm{HO}-\mathrm{OOC}-\mathrm{R} 2+3 \mathrm{CH} 3 \mathrm{OH}=\mathrm{CH} 3-\mathrm{OOC}-\mathrm{R} 2+\mathrm{H} 2 \mathrm{C}-\mathrm{OH} \\
& \begin{array}{ll}
\mathrm{H} 2 \mathrm{O}-\mathrm{OOC}-\mathrm{R} 3 & \mathrm{CH} 3-\mathrm{OOC}-\mathrm{R} 3 \mathrm{H} 2 \mathrm{C}-\mathrm{OH} \\
\text { Cereals } \quad \text { Methanol } & \text { Biodiesel Glycerol }
\end{array}
\end{aligned}
$$

The vegetable oil must be chemically altered or blended with diesel fuel to prevent premature engine failure. Blending, cracking emulsification of vegetable oil may be overcome the problems such as deposit formation, carbon buildup and lubrication oil contamination which otherwise cause premature engine failure.

\section{Literature}

Refaat et al. (2008) have reported transesterification of waste vegetable oil with methanol and potassium hydroxide for the product of biodiesel. The best yield percentage was obtained using a methanol/oil molar ratio of $6: 1$, potassium hydroxide as catalyst $(1 \%)$ and $65 \mathrm{oC}$ temperature for one hour. The yield percentage obtained from vegetable oil was comparable to that obtained from neat vegetable oil which reached 96.15\% under optimum condition. The produced biodiesel fuel, whether from neat vegetable oil or waste vegetable oil, was within the recommended standards of biodiesel fuel. Fan et al. (2009) have performed the two step transesterification reaction of recycled canola oil due ti its higher fatty acids content. The results showed that alkali-catalized that was carried out at $6 / 1$ molar ratio of methanol to oil and $1 \% \mathrm{KOH}$ produced biodiesel.

Theory 
Table1.Taguchi design of experiment technique

\begin{tabular}{|l|l|l|l|}
\hline Exp.No. & A & B & C \\
\hline 1 & 1 & 1 & 1 \\
\hline 2 & 1 & 2 & 2 \\
\hline 3 & 1 & 3 & 3 \\
\hline 4 & 2 & 1 & 2 \\
\hline 5 & 2 & 2 & 3 \\
\hline 6 & 2 & 3 & 1 \\
\hline 7 & 3 & 1 & 3 \\
\hline 8 & 3 & 2 & 1 \\
\hline 9 & 3 & 3 & 2 \\
\hline
\end{tabular}

Variables: A, B, C

Levels: $1,2,3$

Table2.Process parameters selected for standardisation of transesterification process

\begin{tabular}{|l|l|l|}
\hline S.No. & Optimizing parameters & Level selected \\
\hline 1 & Catalyst concentration(\%) & $0.5,0.75,1$ \\
\hline 2 & Alcohol concentration $(\%)$ & $5,10,15$ \\
\hline 3 & Reaction time(min.) & $45,60,75$ \\
\hline 4 & Reaction temperature(C) & 60 \\
\hline
\end{tabular}

Waste cooking oil sample: 160gm.

\section{Procedure}

1. Take $160 \mathrm{gm}$ of waste cooking oil in a conical flask.

2. In a separate flask mix $1 \% \mathrm{KOH} \& 15 \%$ of methanol by weight of WCO.

3. Add this solution to oil sample.

4. Maintain the above sample at $60 \mathrm{oC}$ for $60 \mathrm{~min}$ at constant stiring in water bath shaker.

5. After this put the sample in separating funnel for 24 hours so that glycerine will settle to the bottom and can be drained off.

6. The liquid left in seperatinf funnel is crude biodiesel as it contains alcohol and catalyst in it.

7. Now boil the biodiesel to get pure, moisture free biodiesel.

Table3.Standardisationoftransesterificationprocess parameters regarding waste cooking oil

\begin{tabular}{|c|c|c|c|c|c|c|c|}
\hline S.No & $\begin{array}{c}\text { Catalyst } \\
(\%)\end{array}$ & $\begin{array}{l}\text { Alcoh } \\
\text { ol (\%) }\end{array}$ & $\begin{array}{l}\text { Time } \\
(\mathrm{min})\end{array}$ & $\begin{array}{l}\text { Yield } \\
(\%)\end{array}$ & $\begin{array}{l}\text { Viscocity } \\
\left(\mathrm{mm}^{\wedge} 2 / \mathrm{sec}\right)\end{array}$ & $\begin{array}{l}\text { Flash } \\
\text { Point }\left({ }^{\circ} \mathrm{C}\right)\end{array}$ & $\begin{array}{l}\text { Fire } \\
\text { Point }\left({ }^{\circ} \mathrm{C}\right)\end{array}$ \\
\hline 1 & 0.5 & 5 & 45 & 84.3 & 1.2 & 195 & 245 \\
\hline 2 & 0.5 & 10 & 60 & 90.6 & 2.3 & 190 & 240 \\
\hline 3 & 0.5 & 15 & 75 & 81.84 & 4.17 & 195 & 245 \\
\hline 4 & 0.75 & 5 & 60 & 89.37 & 0.4 & 197 & 242 \\
\hline 5 & 0.75 & 10 & 75 & 93.75 & 3.1 & 100 & 130 \\
\hline 6 & 0.75 & 15 & 45 & 99.2 & 12.5 & 190 & 220 \\
\hline 7 & 1 & 5 & 75 & 75.1 & 7.02 & 192 & 242 \\
\hline 8 & 1 & 10 & 45 & 81.25 & 4.10 & 188 & 240 \\
\hline 9 & 1 & 15 & 60 & 84.37 & 17.15 & 185 & 225 \\
\hline
\end{tabular}

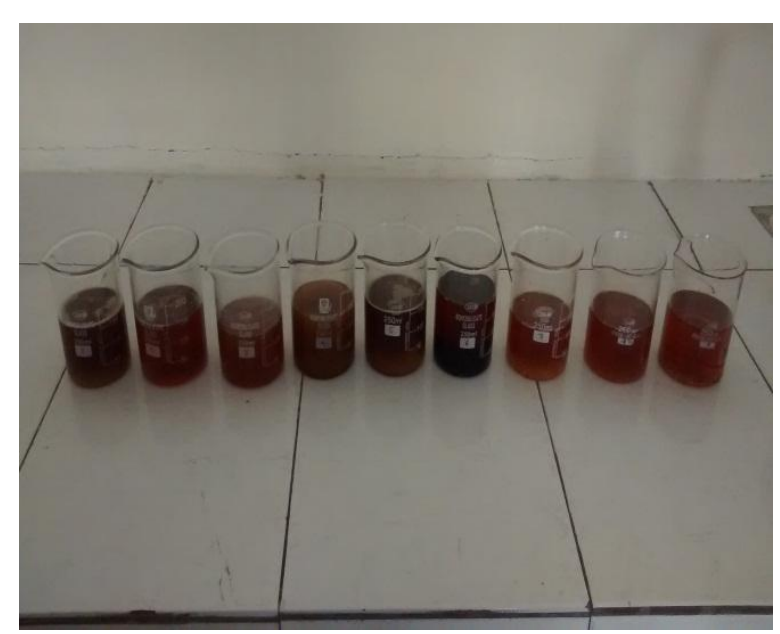

Fig.1 Specimens 


\section{Results}

Analyzing biodiesel achieved under optimum condition

The obtained biodiesel from both applying transesterification process have lower viscocity at $600 \mathrm{C}$. The waste cooking oil could be consumed as fuel in diesel engines but main obstacle to use oil as fuel in diesel as its high viscocity which creates problem in aitomisation of fuel spray and operation of fuel injectors. The obtained resut is sample no. 3. This sample has accurate result with accurate viscocity, flash point and fire point ranges in ASTM standards. Viscocity ranges from 2-6, flash point ranges from 170-200 oC and fire point ranges from $220-250$ oC.

Effect of oil to methanol ratio

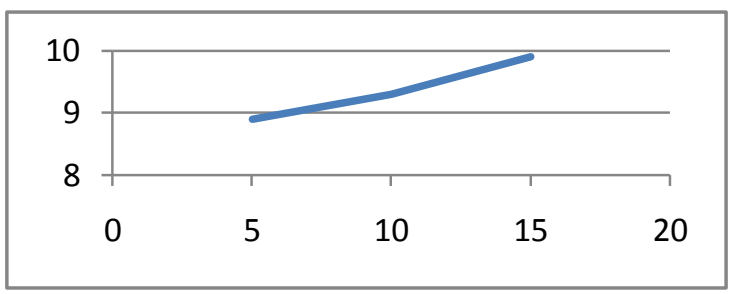

In the graph 1 percentage of methanol is in $\mathrm{x}$ axis and percentage of yield is in $\mathrm{y}$ axis.

\section{Effect of KOH concentration}

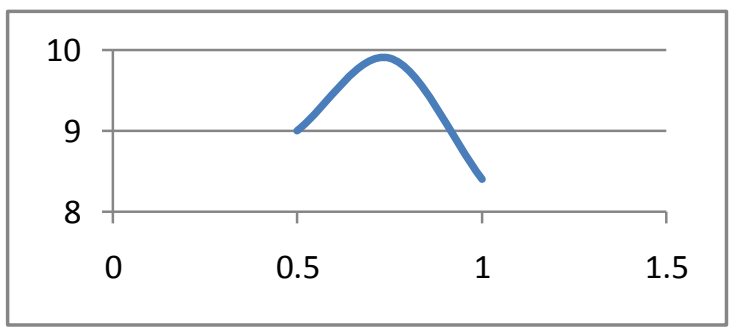

In the graph 2 percentage of $\mathrm{KOH}$ is in $\mathrm{x}$ axis and percentage of yield is in y axis.

\section{Effect of time}

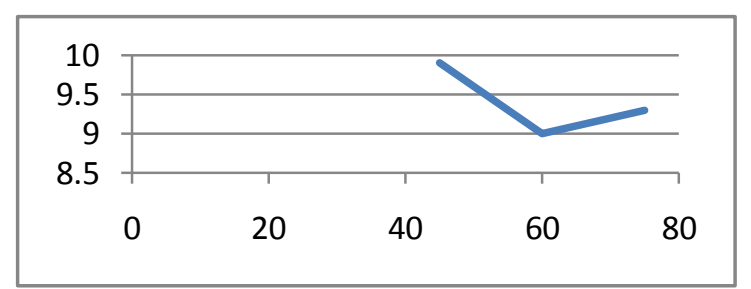

In the graph 3 change in time is in $\mathrm{x}$ axis and percentage of yield is in $\mathrm{y}$ axis.

\section{Conclusion}

The overall studies based on production of biodiesel from waste cooking oil is successful. The produced biodiesel was of good quality within the array of standard method specification and production yield was set up to $99.2 \%$ under optimal condition. The research indicate that the production of biodiesel from waste cooking oil has bit significant difference and also the research highlighted that waste cooking oil could be used potentially by following innovation. The best result is exp. no. 3 with viscocity varies in standard range. Also its flash point and fire point varies in standard range.

\section{Reference}

[1]. Prakash, N., Jose, A., A., Devanasan, M.G. and Viruthagiri, T. (2006),"Optimization of Karanja oil transesterification", Indian journal of chemistry technology.

[2]. Prasad, V.S. Mohapatra, S.K. Sharma, J.K. and Bali, P.L.(2011),"Performance and evaluation of a diesel engine fuelled with filtered Pongamia oil and its standardisation characterstics", Vol.1, pp.65-73.

[3]. Karanwal,P.andwootthikanokkam, S.(2010)," Optimization of biodiesel production from Jatrophacurcas L. oil via alkalicatalyzedmethanolysis", Journal of Sustainable energy and environment,Vol.1, pp.105-109.

[4]. Fan, X., Burton, R. and Austic, G. (2009),"Preparation and characterization of biodiesel produced from recycled canola oil”, The open Fuel and energy science journal, Vol.2, pp.113-118. 